\title{
Callus induction and plant regeneration of Lychnis wilfordii (Regel) Maxim a critically endangered plant in Korea
}

\author{
Kee Hwa Bae $\cdot$ Mi Hyun Lee $\cdot$ Yong Eui Choi $\cdot$ Eui Soo Yoon
}

Received: 26 February 2014 / Revised: 3 March 2014 / Accepted: 17 March 2014

(C) Korean Society for Plant Biotechnology

\begin{abstract}
Lychnis wilfordii (Regel) Maxim is a rare and valued ornamental plant. Germination rate reached $46.6 \%$ when seeds were treated with $100 \mathrm{mg} \cdot \mathrm{l}^{-1} \mathrm{GA}$ (Gibberellic acid). The highest callus induction was observed in the leaf explants of the seedlings on MS medium containing specific concentrations of $0.5 \mathrm{mg} \cdot 1^{-1} \mathrm{BA}\left(\mathrm{N}^{6}\right.$-benzyladenine) and 3.0 $\mathrm{mg} \cdot \mathrm{I}^{-1}$ NAA (a-naphthalene acetic acid). The adventitious shoot was formed in $97.3 \%$ of calli on 1/2 WPM (Woody Plant Medium) medium. Shoot elongation of in vitro propagated plantlets was no difference among various medium. The plantlets grew well after transferring to the pot. This in vitro propagation protocol should be useful for conservation of this endangered plant.
\end{abstract}

Keywords callus, endangered plant, in vitro, germination, L. wilfordii

\section{Introduction}

The genus Lychnis belongs to the family Caryophyllaceae and consists of about 30 species in the world. Lychnis spp. are distributed throughout the temperate regions of the Northern Hemisphere, from East Asia to Europe (Magnus

\section{K. H. Bae}

National Institute of Biological Resources, 42 Hwangyeong-ro, Seo-gu, Incheon, 404-708, Republic of Korea

M. H. Lee

R\&D center, Asiaseed Co. Ltd., Icheon, 447-2, Gyeonggi

Province, Republic of Korea

Y. E. Choi

Division of Forest Resources, College of Forest and Environmental Sciences, Kangwon National University, Chuncheon, Kangwon-do 200-701, Republic of Korea

\section{E. S. Yoon $(\bowtie)$}

Department of Biology, College of Nature Sciences, Kongju

National University, Kongju 314-701, Republic of Korea

e-mail: yes@kongju.ac.kr et al. 2008), and four Lychnis spp. are native to Korea (Lee 1974). Some species of Lychnis spp. are frequently grown in Korea for horticultural use.

Lychnis wilfordii (Regel) Maxim is a perennial and narrowly distributed in Kangwon province of Korea. Also, it is rare and critically endangered species which is subjected to strict protection as an endemic plant. The population size declines rapidly. For this reason, the Ministry of Environment (MEV) has designated the species as 'Threatened to extincts : the second grade for preservation' (Lee and Choi 2006). Also, the reproduction of this species by seeds is rarely used due to poor seed germination and low seed production.

L. wilfordii is a valued omamental plant with orange-red flowers. However, little attention was paid to this material by Korean botanists and horticulturists. The main reason for this is the limitation of suitable environments and low productivity of the species. In nature, the species propagates through seed and vegetative perennial rootstock. According to our preliminary investigations on propagation of $L$. wilfordii via seed, we found that seed germination took $2 \sim 3$ months and was sporadic from ex vitro or in vitro culture. Meanwhile, vegetative propagation was not possible as the process of rooting was too slow. Therefore, the development of an in vitro protocol will be of great importance for conservation and sustainable utilization of this species. However, propagation protocols for this species in vitro have not yet been reported.

The purpose of this study of $L$. wilfordii in vitro propagation methods was to improve the germination rates of seeds and develop a protocol for in vitro propagation via organogenesis.

\section{Materials and methods}

Plant material and seed germination test

Seeds of $L$. wilfordii were collected from a wild population of Mt. Odae National Park in Korea late September of 
2010. Mature seeds of $L$. wilfordii were scarified by immersion in $70 \% \mathrm{EtOH}$ for $1 \mathrm{~min}$ and then sterilized with $1 \%$ sodium hyporchloride $(\mathrm{NaOC})(\mathrm{v} / \mathrm{v})(5 \%$ of sodium hypochlorite, Sigma, USA) and a few drops of Tween-20 (Sigma, USA) for $30 \mathrm{~min}$. For the $\mathrm{GA}_{3}$ treatment, seeds were soaked in $100 \mathrm{mg} \cdot \mathrm{l}^{-1} \mathrm{GA}_{3}$ solution for $24 \mathrm{~h}$ before incubation. The seeds were washed 5 times in sterile water and placed into petri-dishes containing hormone-free MS (Murashige and Skoog 1962) medium under white fluorescent lights (30 $\mu$ $\mathrm{mol} \mathrm{m} \mathrm{m}^{-2}$ ) on a $16 \mathrm{~h}$ photoperiod or in the dark at $25^{\circ} \mathrm{C}$. The germination rate was tested after 8 weeks of culture. Thirty seeds were incubated for each treatment and repeated five times, and the seeding used in subsequent experiments.

Effects of explant type and PGR's on callus induction

After cutting the leaf, stem and root explants into $10 \mathrm{~mm}$ in sizes from in vitro plantlet (Fig 2A), they were cultured on MS medium supplemented with auxins $(0,1.0$ and 3.0 $\mathrm{mg} \mathrm{l}^{-1} \mathrm{NAA}$ : a-naphthalene acetic acid, $0,1.0$ and $3.0 \mathrm{mgl}^{-1}$ IAA : indole acetic acid ) and/or cytokinin $\left(0,0.5 \mathrm{mgl}^{-1}\right.$ BA : $\mathrm{N}^{6}$-benzyladenine). All media were supplemented with $30 \mathrm{~g} \mathrm{l}^{-1}$ sucrose and solidified with $8.0 \mathrm{~g} \mathrm{I}^{-1}$ plant agar, and then adjusted to $\mathrm{pH} 5.8$ before autoclaving at $121^{\circ} \mathrm{C}$ for $20 \mathrm{~min}$. Calli were maintained under cool white fluorescent lights $\left(30 \mu \mathrm{mol} \mathrm{m} \mathrm{m}^{-2} \mathrm{~s}^{-1}\right)$ on a $16 \mathrm{~h}$ photoperiod at $25^{\circ} \mathrm{C}$. The frequency of callus induction was evaluated after 12 weeks of culture. Thirty explants (leaf, stem and root) were incubated for each treatment and repeated five times.

In vitro plant regeneration

Calli were transferred to WPM (Loyd and McCown 1980), half-strength WPM, one-third strength WPM medium, MS, half-strength MS, and one-third strength MS medium for the plant regeneration. The culture room was maintained at $25^{\circ} \mathrm{C}$ with a $16 \mathrm{~h}$ photoperiod under $30 \mu \mathrm{mol} \mathrm{m} \mathrm{m}^{-2}$ white fluorescent light. Adventitious shoot formation rate was evaluated by counting plantlets with well-developed shoot primordia after 4 weeks of culture. And, plants with better roots were transplanted into a mixture composed of vermiculite and pealrite (1:1) in the single pot. Plantlet height was evaluated by measuring average length of shoots and roots after 4 weeks of culture.

Statistical analysis

All data were analyzed using ANOVA and expressed as means \pm standard error (SE). To examine significant differences among the treatments, multiple comparison tests were then performed by Duncan's multiple range test at $\mathrm{p} \leq 0.05$ (SAS 2001).

\section{Results and dis cussions}

Treatment of $\mathrm{GA}_{3}$ on seed germination

The germination rate of seeds was increased with $\mathrm{GA}_{3}$ treatment as shown in Figure 1. The germination rate reached $46.6 \%$ when seds were treated with $100 \mathrm{mgl}^{-1} \mathrm{GA}_{3}$. However, the germination rate was still not sufficient for production of the species by seed propagation. Therefore, in vitro propagation of $L$. wilfordii was performed in the subsequent experiments. Based on our preliminary study, L. wilfordii seeds have a poor and unpredictable germination rate. The result suggested that $L$. wilfordii seeds have deep dormancy. It has been reported that approaches to break seed dormancy such as hormonal, temperature, etc. are necessary (Seiler 1998; Mabberley 1989). GA 3 treatment was resulted in improve germination of many plant species (Nicolas et al. 1996; Rehman and Park 2000). In the present study, it was found that the germination rate was increased in of $\mathrm{GA}_{3}$ treated seeds comparison to the control treatments.

\section{Callus induction}

Callus formation varied significantly depending on kind of explants and plant growth regulator (PGR) in L. wilfordii (Table 1). When explants were cultured on medium with BA, callus formation was more efficient compared to the

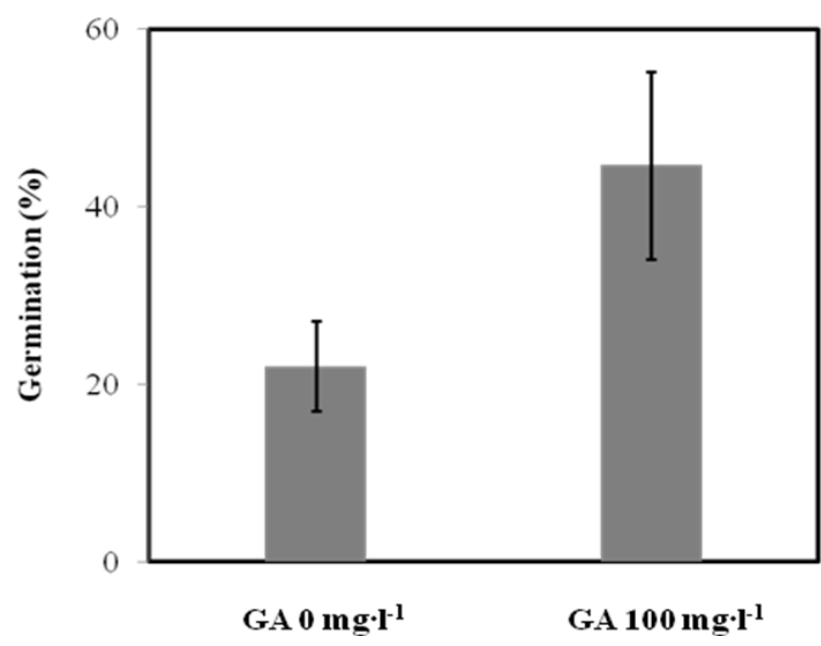

Fig. 1 Effect of $\mathrm{GA}_{3}$ on germination of L. wilfordii: Thirty seeds were incubated for each treatment with five replicates. Germination rate (\%) was recorded after 4 weeks of culture 
Table 1 Effects of NAA and IAA in combination with BA on callus formation from leaf, stem and root explants of $L$. wilfordii. MS medium containing $30 \mathrm{gl}^{-1}$ sucrose. Data were collected after 12 weeks of culture

\begin{tabular}{|c|c|c|c|c|c|}
\hline \multicolumn{3}{|c|}{ PGR's $\left(m g l^{-1}\right)$} & \multicolumn{3}{|c|}{ Callus formation (\%) } \\
\hline BA & NAA & IAA & Leaf & Stem & Root \\
\hline \multirow{6}{*}{0} & 0 & 0 & 0 & 0 & 0 \\
\hline & 1.0 & 0 & $33.3 \pm 5.3^{\mathrm{e}}$ & $22.7 \pm 4.3^{\mathrm{e}}$ & $8.7 \pm 3.8^{\mathrm{ab}}$ \\
\hline & 3.0 & 0 & $34.7 \pm 5.1^{\mathrm{e}}$ & $30.0 \pm 5.3^{\mathrm{d}}$ & $9.3 \pm 2.8^{\mathrm{a}}$ \\
\hline & 0 & 0 & 0 & 0 & 0 \\
\hline & 0 & 1.0 & $30.0 \pm 5.3^{\mathrm{e}}$ & $26.7 \pm 5.3^{\mathrm{d}}$ & $11.3 \pm 3.8^{\mathrm{a}}$ \\
\hline & 0 & 3.0 & $33.3 \pm 6.2^{\mathrm{e}}$ & $28.7 \pm 3.8^{\mathrm{d}}$ & $13.3 \pm 5.3^{\mathrm{a}}$ \\
\hline \multirow{6}{*}{0.5} & 0 & 0 & 0 & 0 & 0 \\
\hline & 1.0 & 0 & $80.7 \pm 9.5^{\mathrm{b}}$ & $71.3 \pm 8.7^{\mathrm{a}}$ & $11.3 \pm 3.8^{\mathrm{a}}$ \\
\hline & 3.0 & 0 & $86.6 \pm 4.3^{\mathrm{a}}$ & $73.3 \pm 11.8^{\mathrm{a}}$ & $12.7 \pm 4.9^{\mathrm{a}}$ \\
\hline & 0 & 0 & 0 & 0 & 0 \\
\hline & 0 & 1.0 & $52.0 \pm 9.6^{\mathrm{d}}$ & $48.0 \pm 3.8^{\mathrm{c}}$ & $13.3 \pm 4.7^{\mathrm{a}}$ \\
\hline & 0 & 3.0 & $67.3 \pm 5.5^{\mathrm{c}}$ & $64.7 \pm 5.6^{\mathrm{ab}}$ & $14.0 \pm 4.9^{\mathrm{a}}$ \\
\hline
\end{tabular}

Data are the means \pm SD, of five time experiments, $n=30$. Different alphabetical letters are significantly different according to Duncun's multiple range test at $\mathrm{P} \leq 0.05$.
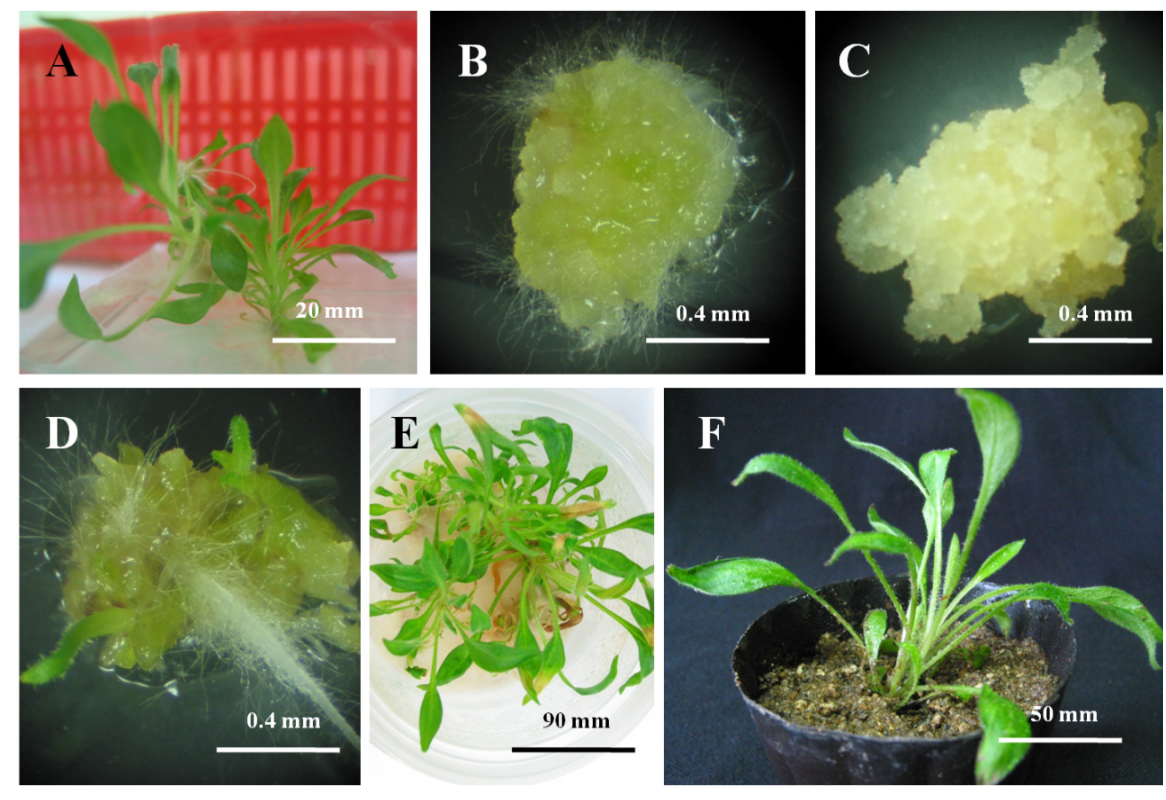

Fig. 2 Plant regeneration from callus derived from $L$ wilfordii. A: In vitro seedling of $L$. wilfordii. B: Initiation of callus induction from leaf explants on MS medium with $0.5 \mathrm{mgl}^{-1} \mathrm{BA}$ and $3.0 \mathrm{mgl}^{-1} \mathrm{NAA}$. C: Initiation of callus induction from root explants on MS medium with $0.5 \mathrm{mgl}^{-1} \mathrm{BA}$ and $3.0 \mathrm{mgl}^{-1}$ NAA. D: Conversion of shoot and root on 1/2MS medium without PGR's after 4 weeks of culture. E: Proliferation of shoots on 1/2MS medium without PGR's after 8 weeks of culture. F: Plantlet in sterile soil, vermiculite and pealrite (1:1) mixture for 10 day

explants without BA treatment. Leaf explants formed callus after 8 weeks of culture, but stem and root generated callus from cut surfaces after 10 weeks of culture. Calli of leaf (Fig. 2B) and root (Fig. 2C) were compact, globular and yellowish on MS medium with both $0.5 \mathrm{mgl}^{-1} \mathrm{BA}$ and 3.0 mg $1^{-1}$ NAA after 12 weeks of culture, but control (non-treated PGR) did not form callus (Table 1). However, stem and root explants exhibited $73.3 \%$ and $12.7 \%$ callus formation, respectively (Table 1). Callus induction in monocots requires long time for its initiation (Geier 1986). It was reported that the induction of callus was difficult and the proliferation of initiated callus was very slow and somehow difficult to maintain in other allium species (Zheng et al. 1998; Luciani et al. 2006). 
Table 2 Effect of various kinds of medium on adventitious shoot formation and plantlet conversion of $L$. wilfordii from callus. Adventitious shoot formation (\%) was collected after 8 weeks of culture. Plantlet conversion was collected after 12 weeks of culture

\begin{tabular}{cccc}
\hline \multirow{2}{*}{ Media } & Adventitious shoot formation $(\%)$ & \multicolumn{2}{c}{ Plantlet conversion } \\
\cline { 3 - 4 } & & Length of shoot $(\mathrm{cm})$ & Length of root $(\mathrm{cm})$ \\
\hline WPM & $82.0 \pm 6.5^{\mathrm{cd}}$ & $12.0 \pm 1.6^{\mathrm{a}}$ & $3.0 \pm 0.7^{\mathrm{b}}$ \\
$1 / 2 \mathrm{WPM}$ & $99.3 \pm 1.5^{\mathrm{a}}$ & $13.0 \pm 1.0^{\mathrm{a}}$ & $2.8 \pm 0.8^{\mathrm{c}}$ \\
$1 / 3 \mathrm{WPM}$ & $96.7 \pm 4.7^{\mathrm{ab}}$ & $12.6 \pm 1.5^{\mathrm{a}}$ & $2.8 \pm 0.8^{\mathrm{c}}$ \\
MS & $86.7 \pm 5.3^{\mathrm{c}}$ & $13.0 \pm 1.0^{\mathrm{a}}$ & $3.4 \pm 1.1^{\mathrm{a}}$ \\
$1 / 2 \mathrm{MS}$ & $97.3 \pm 4.3^{\mathrm{ab}}$ & $12.4 \pm 1.1^{\mathrm{a}}$ & $3.0 \pm 0.7^{\mathrm{b}}$ \\
$1 / 3 \mathrm{MS}$ & $97.3 \pm 4.3^{\mathrm{ab}}$ & $12.0 \pm 1.0^{\mathrm{a}}$ & $3.4 \pm 0.9^{\mathrm{a}}$ \\
\hline
\end{tabular}

Data are the means $\pm \mathrm{SD}$, of five time experiments, $n=30$. Different alphabetical letters are significantly different according to Duncun's multiple range test at $\mathrm{P} \leq 0.05$.

In vitro plant regeneration

To determine adventitious shoot induction from callus, both types of callus (compact and friable ones) were transferred onto media (WPM, 1/2WPM, 1/3WPM, MS, 1/2MS, and $1 / 3 \mathrm{MS})$. After 20 to 25 days of culture, calli turned greenish (Fig. 2D) and several adventitious shoot regenerated on 1/2MS medium (Fig. 2E). The highest adventitious shoot induction rate was obtained in 1/2WPM medium (99.3\%) (Table 2). However, there was not a remarkable difference on the growth of plantlets among the six media. The height of in vitro propagated plants in pot was around $20 \sim 35 \mathrm{~cm}$ (Fig 2F). Adventitious shoot regeneration on different media may be due to the differences of $\mathrm{NO}_{3}{ }^{-} \mathrm{NH}_{4}{ }^{+}$ratio, an important factor on nitrogen uptake and $\mathrm{pH}$ regulation during plant tissue culture (Fracago and Echeverrigaray 2001). Lower $\mathrm{NO}_{3}^{-} \mathrm{NH}_{4}^{+}$ratio in $\mathrm{B} 5$ medium stimulated shoot conversion and growth from other allium species (Camborg et al. 1968; Chu et al. 1975; Luciani et al. 2006). In vitro culture technique is an alternative ways for germplasm conservation and micropropagation of valuable endangered plants. It has the advantages of preserving healthy plant material in a small space, easy and rapid multiplication for international exchange as well as cost reduction. Generally, addition of BA to the medium could induce the formation of adventitious buds (Ayabe et al. 1995; Ayabe et al. 1998; Guo et al. 2005; Xu et al. 2008). In the present study, the multiplication coefficient rose with the treatment of BA and NAA, respectively, but there was no interactive effects of BA and NAA.

In conclusion, we established the tissue culture system to propagate $L$. wilfordii and this technique may be applicable to commercially propagated the endangered $L$. wilfordii speices.

\section{Acknowl edgement}

This work was supported by the research grant of the Kongju National University in 2012.

\section{References}

Ayabe M, Sumi S (1998) Establishment of a novel tissue culture method, stem-disc culture and its practical application to micropropagation of garlic (Allium sativum L.). Plant Cell Rep, 17:773-779

Ayabe M, Taniguchi K, Sumi SI (1995) Regeneration of whole plants from protoplasts isolated from tissue cultured shoot primordia of garlic (Allium sativum L.). Plant Cell Rep, $15: 17-21$

Chu CC, Wang CC, Sun CS (1975) Establishment of an efficient medium for anther culture of rice through comparative experiments on the nitrogen sources. Sci Sin 18:659-668

Fracago F, Echeverrigaray S (2001) Micropropagation of Cunila galioides, apopularmedicinal plant of south Brazil.Plant Cell Tissue Organ Cult 64: 1-4

Gamborg O, Miller R, Ojima K (1968) Nutrient requirements of suspension cultures of soybean root cells. Exp Cell Res 50: $151-158$

Geier T (1986) Anthurium. In: Evans, P.V., Sharp, D.A., Bajal, Y.P.S. (Eds.), Handbook of Plant Cell Culture, vol. 5. Collier Macmillan/Macmillan. New York/London pp228-252

Guo DP, Zhu ZJ, Hu XX, Zheng SJ (2005)Effect of cytokinins on shoot regeneration from cotyledon and leaf segment of stem mustard (Brassica juncea var. tsatsai). Plant Cell Tissue Organ Cult, 83:123-127

Lee YN (1974) New taxa on Korean flora (1). Kor J Bot 17:33-35

Lee JS, Choi BH (2006) Distribution and red data of wild orchids in the Korean Peninsula. Korea J Plant Taxon 36:335-360

Lloyd E, MoCown B(1980)Commercially feasible micropropagation of mountain laurel (Kalmia latifolia) by use of shoot tip culture. Comb Proc Int Plant Prop Soc 30:421-427

Luciani GF, Mary AK, Pellegrini C, Curvetto NR (2006)Effects of 
explants and growth regulators in garlic callus formation and plant regeneration. Plant Cell Tissue Organ Cult 87:139-143

Magnus P, Abel G, Sileshi N, Jan S, Christian B (2008) Colonization and diversification in the African 'sky islands' by Eurasian Lychnis L. (Caryophyllaceae). J Biogeography 35:1016-1029

Mabberley DJ (1989) The plant-book: aportable dictionary of the higher plants. Cambridge: Cambridge University Press

Murashige T, SkoogF (1962) A revised medium for rapid growth and bioassays with tobacco tissue culture. Physiol Plant 15: 473-497

Nicolas C, Nicolas G, RodriguezD (1996)Antagonistic effects on abscisic acid and gibberellic acid on the breaking of domancy of Fagus sylvatica seeds. Physiol Plant 96:244-250

Rehman S, Park IH(2000) Effect of scarification, GA and chilling on the germination of golden rain-tree (Koelreuteria paniculata
Laxm.) seeds. Sci Hort 85:319-324

SAS (2001) SAS/STAT User's guide (8.02) SAS Institute Inc., Cary, NC, USA

Seiler GJ (1998) Seed maturity, storage time and temperature, and mediatreatment effects on germination of two wild sunflowers. Agron J 90:221-226

XuZ, Um YC, Kim CH, Lu G, Guo DP, Liu HL, Bah AA, Mao A (2008) Effect of plant growth regulators, temperature and sucrose on shoot proliferation from the stem disc of Chinese jiaotou (Allium chinense) and in vitro bulblet formation. Acta Physiol. Plant, 40:521-528

Zheng SJ, Henken B, Sofiari E, Jacobsen E, Krens FA, Kik C (1998) Factorsinfluencinginduction, propagation and regeneration of mature zygotic embryo-derived callus from Allium cepa. Plant Cell Tissue Organ Cult 53:99-105 